\title{
$\left[{ }^{14} \mathrm{C}\right]$ Urea の体内動態(第 2 報）; 非絶食ラットにおける \\ 吸収, 分布, 代謝, 排泄
}

\author{
野村 成章, 松本 聡, 西村 由香, 笠井 英史, 南 博文 \\ 寺内 嘉章, 藤井 敏彦
}

\section{Pharmacokinetic Studies of $\left[{ }^{14} \mathrm{C}\right]$ Urea (2); Absorption, Distribution, Metabolism and Excretion after Administration of $\left[{ }^{14} \mathrm{C}\right]$ Urea in Non-Fasted Rats}

\author{
Naruaki Nomura, Satoshi Matsumoto, Yuka Nishimura, Hidefumi Kasai, Hirofumi Minami, \\ Yoshiaki TERAUCHI and Toshihiko FUJII
}

Department of Pharmacokinetics, Developmental Research Laboratories, Dainippon Pharmaceutical Co., Ltd., Osaka

Summary: Absorption, distribution, metabolism and excretion after a single intravenous and oral administration of $\left[{ }^{14} \mathrm{C}\right]$ urea at a main dose of $2 \mathrm{mg} / \mathrm{kg}$ were investigated in non-fasted rats. Comparison of the pharmacokinetics in rats between under non-fasted and fasted conditions was also investigated.

1. The radioactivity levels in plasma were decreased biphasically with $\mathrm{t}_{1 / 2 \alpha}$ of $2-3 \mathrm{hr}$ and $\mathrm{t}_{1 / 2 \beta}$ of $6-11 \mathrm{hr}$, irrespective of administration routes and doses. After oral administration at doses of 2, 62.5, 250 and $1000 \mathrm{mg}$ $/ \mathrm{kg}$, the $\mathrm{C}_{\max }$ and $\mathrm{AUC}_{0-\infty}$ were virtually proportional to the administered doses, suggesting linear-pharmacokinetics within the examined dose range.

2. The radioactivity levels in plasma and tissues reached $\mathrm{C}_{\max }$ at $0.5-1 \mathrm{hr}$ after oral administration. The concentration in the kidney, which was 2.4 times as high as that in plasma, was the highest in the examined tissues. The concentrations in other tissues were similar to, or lower than the plasma concentration. After the $\mathrm{C}_{\max }$, the concentrations in most tissues decreased in almost parallel with the plasma concentration.

3. In plasma at $1 \mathrm{hr}$ after oral administration, only the unchanged drug was observed in the plasma radioactivity. On the other hand, at $8 \mathrm{hr}$, about $70 \%$ and $30 \%$ of the plasma radioactivity were unchanged drug and unknown components, respectively. In urine for $24 \mathrm{hr}$ after dosing, only the unchanged drug was also observed, irrespective of administration routes.

4. Within $96 \mathrm{hr}, 73.1 \%, 1.6 \%$ and $20.1 \%$ of dosed radioactivity were excreted in urine, feces and expired air after intravenous administration, and $54.0 \%, 1.0 \%$ and $42.9 \%$ after oral administration, respectively. The bioavailability estimated from the ratio of urinary excretion of urea after oral administration to that after intravenous administration was $74 \%$.

5. Feeding condition in rats enhanced metabolism/decomposition of urea and influenced its plasma concentration-time profiles and excretion profile.

Key words: Urea, Diagnosis of Helicobacter pylori infection, Absorption, Distribution, Metabolism, Excretion, Expired air, Non-fasted rats, Fasted rats

\section{緒言}

Helicobacter pylori (H. Pylori) 感染の診断法として, ${ }^{13} \mathrm{C}$ または ${ }^{14} \mathrm{C}$ 標識 urea (以下， $\left[{ }^{13} \mathrm{C}\right]$ または $\left[{ }^{14} \mathrm{C}\right]$ urea と記載)を用いた呼気試験 (Urea Breath Test)が有用で あることが見い出され闶吕)，我国においては， $\left[{ }^{13} \mathrm{C}\right]$ urea が猃断薬として開発されつつある.

$\mathrm{CD}-13\left(\left[{ }^{13} \mathrm{C}\right]\right.$ urea $)$ は当社において開発された $H$.
Pylori 感染診断薬である. 本研究では urea の体内動態 を明らかにすることを目的に， $\left[{ }^{14} \mathrm{C}\right]$ urea を用いてラッ 卜における吸収, 分布, 代謝, 排泄について検討した。 本診断が経口投与された $\left[{ }^{13} \mathrm{C}\right]$ urea の胃内にお打る代 謝·分解に基づき実施されるという性質上，食餌の影響 を検討することは重要であるものと考えられることか ら，絶食下抢よび非絶食下に抢ける一連の体内動態試験 を実施した，前報4)では絶食下のラットにおける $\left[{ }^{14} \mathrm{C}\right]$

大日本製薬株式会社 開発研究所 薬物動態研究部 ₹564-0053 大阪府吹田市江の木町 33-94 
ureaの体内動態について検討した結果，静脈内および 経口投与後いずれも urea はほとんど代謝を受けず，速 やかに尿中へ排泄されることを明らかにした。本報では 非絶食下のラットに $\left[{ }^{14} \mathrm{C}\right]$ urea を投与後の体内動態につ いて検討し, 絶食下での体内動態と比較することにより 食餌の影響の観点から考察した。 その結果, 食慨により $\left[{ }^{14} \mathrm{C}\right]$ urea の体内動態が变動する知見が得られたので報 告する.

\section{実験材料および方法}

\section{1. 標識化合物および化合物}

市販の $\left[{ }^{14} \mathrm{C}\right]$ urea (Code CFA. 41, Batch 117B; Amersham International plc, Bucks, U.K.) を使用した4)。本 標識化合物の比放射能は $35.2 \mathrm{MBq} / \mathrm{mg}$ であり, 放射化 学的純度はエタノール: 蒸留水 : $25 \%$ アンモニア水= $20 / 4 / 1(\mathrm{v} / \mathrm{v} / \mathrm{v})$ を展開溶媒とした薄層クロマトグラフ ィー(TLC plate; Silica gel $60 \mathrm{~F}_{254}$, No. 5715: E.Merck) による検定の結果，99\%以上であった。なお実験には 非標識 urea (Code No. 215-00611, Lot. No. SKN7132 : 和光純薬(侏)で適宜希釈して用いた。 その他の化学試薬 および溶媒は全て市販特級品を用いた.

\section{2. 実験動物}

実験には 7 9 週齢, 体重 238 359 g の雄性 SD 系ラ ット (日本クレア秼)を用いた。 室温 $20-26^{\circ} \mathrm{C}$, 湿度 $40-$ $70 \%$, 照明 12 時間明暗サイクルの条件下の部屋で予備 飼育をした後，各試験に供した。試験期間中は個別の ケージに収容し, 同条件の部屋で試験を実施した.ラッ トは予備飼育および試験期間中を通して飼料 $\mathrm{CE}-2$ (日 本クレア(侏)および水を自由に摄取させた.

\section{3. 投与薬液の調製および投与方法}

静脈内および経口投与薬液の調製および投与方法は既 報と同様に実施した ${ }^{4)}$ 。各試験における用量は，全身 オートラジオグラフィー試験は $3.7 \sim 7.4 \mathrm{MBq} / 2 \mathrm{mg} /$ $\mathrm{mL} / \mathrm{kg}$ ，その他の試験は $1.85 \mathrm{MBq} / 2 \sim 1000 \mathrm{mg} / \mathrm{mL} /$ $\mathrm{kg}$ で実施した.

\section{4. 血漿中放射能濃度の測定}

非絶食下，ラットに $\left[{ }^{14} \mathrm{C}\right]$ urea を $2 \mathrm{mg} / \mathrm{kg}$ の用量で 静脈内投与後および $2,62.5,250,1000 \mathrm{mg} / \mathrm{kg}$ の用量で 経口投与後, $5^{* 1}, 15,30$ 分， $1,2,4,6,8,10,24,48,72$ 時間 $(* 1$ 静脈内投与群のみ)に採血した，血漿試料の調製 および測定方法は既報と同様に実施した4).

\section{5. 臓器 - 組織中放射能濃度の測定}

非絶食下，ラットに $\left[{ }^{14} \mathrm{C}\right]$ urea を $2 \mathrm{mg} / \mathrm{kg}$ の用量で 経口投与後，30 分，1，4，8，24，72 時間にエーテル麻酔
下，へパリン処理した注射器 (テルモ)で腹部大動脈より 採血を行い脱血死させた後，脳，松果体，下垂体，甲状 腺, 副腎, 心臓, 大動脈(胸部), 脾臓, 胸腺, 腸間膜リ ンパ節, 顎下リンパ節, 顎下腺, 舌, 肝蔵, 膵蔵, 胃, 小腸, 大腸, 胃内容物, 小腸内容物, 大腸内容物, 気 管, 肺, 腎臓, 膀胱, 精巣, 精巣上体, 前立腺, 精囊 腺, 眼球, ハーダー腺, 筋肉 (大腿部), 脂肪, 褐色脂 肪，皮膚，骨(大腿部)，骨髄を採取した。

採取した血液は一部を放射能測定用に供し，残りは遠 心 $\left(950 \times \mathrm{g}, 4^{\circ} \mathrm{C}, 10\right.$ 分) して血漿と赤血球に分離した. 血漿はその一定量を, 消化管内容物は生理食塩水に懸 濁, 撹拌均質化した後その一定量をバイアルに採り, Aquasol-2 と直接混和した. 血液抢よび赤血球はその一 定量をバイアルに採り，適量のエタノールおよび $30 \%$ 過酸化水素を加え脱色した後, 組織溶解剤 Soluene-350 (Packard)を加え溶解し, シンチレータカクテル Omnifluor (Omnifluor 粉末 (Packard)を Toluene に溶解し て調製）と混和した，骨，気管は自動燃焼装置 ASC-113 (Aloka Co., Ltd.) で然焼し, 発生した ${ }^{14} \mathrm{CO}_{2}$ ガスを吸収 剤 Carbo-Sorb (Packard) で捕集し, シンチレータカク テル Permafluor $\mathrm{E}^{+}$(Packard) と混和した. その他の 組織は全量またはその一部を直接バイアルに採り, Soluene-350を加え溶解し, Omnifluor と混和した．放射 能の測定に供した残りの経口投与後 1 および 8 時間の 血漿は代謝物組成の検討に供した.

\section{6. 全身オートラジオグラムの作製}

全身オートラジオグラムの作製は既報5) に準じて行っ た.すなわち, 非絶食下, ラットに $\left[{ }^{14} \mathrm{C}\right]$ urea を $2 \mathrm{mg} /$ $\mathrm{kg}$ の用量で経口投与後, $1,4,8,24,48$ 時間にエーテル 吸入により麻酔死させ，直ちに被毛を刈り取りドライア イスーアセトン中で凍結した。凍結ラットをミクロトー ムステージ上に 4\%カルボキシメチルセルロースナトリ ウム(Daicel Chemical Industries, Ltd.)のペーストで包 埋し, ドライアイスーアセトン中で凍結して固定した. 縦断面凍結切片 (厚さ $40 \mu \mathrm{m}$ ) をCryo microtome 450 MP (Palmstiernas Mekaniska Verkstad AB., Sweden) を用いて作製した．凍結切片は凍結乾燥した後，保護膜 で皮覆し，X線フィルムKodak SB (Eastman Kodak Co., USA）と 22 日間密着露出した後, X線フィルムを 現像し，全身オートラジオグラムを作成した。

\section{7. 尿, 粪および呼気中放射能排泄率の測定}

非絶食下，ラットに $\left[{ }^{14} \mathrm{C}\right]$ urea を $2 \mathrm{mg} / \mathrm{kg}$ の用量で 静脈内および経口投与後の尿, 糞および呼気中放射能排 泄率を既報と同様の方法で測定した4). 


\section{8. 血漿および尿中代謝物組成の検討}

非絶食下，ラットに $\left[{ }^{14} \mathrm{C}\right]$ urea $2 \mathrm{mg} / \mathrm{kg}$ の用量で 経口投与後 1 および 8 時間の血漿および静脈内および 経口投与後 24 時間までの尿中代謝物組成を既報4) と同 様に，薄層クロマトグラフィー法により検討した.

\section{9. 放射能の測定}

放射能の測定は液体シンチレーションカウンター, Tri-Carb 2000CA, 2200CA (Packard)で行った. なお, 計数效率は外部線源標準法で補正した. 放射能の測定信 頼限界は試料放射能の計数值 $(\mathrm{cpm})$ の標準偏差が計数值 の $5 \%$ に等しくなる場合とし，これを越える場合，測定 信頼限界未満とした.

\section{0. データの処理}

濃度および薬動学的パラメーターの算出, 試験成績の 表示は既報と同様に実施した4).

\section{結果}

\section{1. 血漿中放射能濃度}

非絶食下, ラットに $\left[{ }^{14} \mathrm{C}\right]$ urea を $2 \mathrm{mg} / \mathrm{kg}$ の用量で 静脈内投与後㧍よび $2,62.5,250,1000 \mathrm{mg} / \mathrm{kg}$ の用量で 経口投与後の血漿中放射能濃度推移を Fig. 1 亿，それ らより算出した薬動学的パラメーターを Table I に示す. $2 \mathrm{mg} / \mathrm{kg}$ 静脈内投与後, 血漿中放射能濃度は二相性に
減少し, $t_{1 / 2}$ は $\alpha$ 相 1.7 時間 $\left(t_{1 / 2 \alpha}\right), \beta$ 相 6.2 時間 $\left(t_{1 / 2 \beta}\right)$ であった. 同用量経口投与後, 血漿中放射能濃度は投与 後 1 時間で $\mathrm{C}_{\max } 1.10 \mu \mathrm{g}$ eq. $/ \mathrm{mL}$ に達し, $\mathrm{t}_{1 / 2 \alpha} 2.5$ 時間, $\mathrm{t}_{1 / 2 \beta} 7.5$ 時間と静脈内投与後とほぼ同様に二相性に減少 した. $62.5,250,1000 \mathrm{mg} / \mathrm{kg}$ を経口投与後の血漿中放 射能濃度は, $2 \mathrm{mg} / \mathrm{kg}$ 経口投与後とほほ同様の $\mathrm{t}_{1 / 2}(\alpha$ 相 1.9 2.1 時間, $\beta$ 相 8.7 10.4 時間) で二相性に減少 した. $2 \sim 1000 \mathrm{mg} / \mathrm{kg}$ の用量範囲で $\mathrm{C}_{\max }$ と $\mathrm{AUC}_{0-\infty}$ は 用量にほぼ比例して増加した。

\section{2. 臓器 $\cdot$ 組織中放射能濃度}

非絶食下，ラットに $\left[{ }^{14} \mathrm{C}\right]$ urea $2 \mathrm{mg} / \mathrm{kg}$ の用量で 経口投与後の組織中放射能濃度および組織/血漿中放射 能濃度比をそれぞれ Table II に示す，血漿および各組 織中濃度は投与後 30 分ないし 1 時間で最高濃度に達し た. 投与後 30 分では腎臓中濃度が最も高く, 血漿中濃 度 $1231 \mathrm{ng}$ eq. $/ \mathrm{mL}$ の 2.4 倍であり，ついで投与部位で ある胃が血漿の 1.5 倍であった. 膀胱, 肝蔵, 膵臓, 血 液および骨䯣中濃度は血漿の $0.9 \sim 0.8$ 倍, 脾臓, 顎下 腺, 下垂体，胸腺，腸間膜リンパ節，肺，䫈下リンパ 節, 前立腺, 副腎, 舌, 心臓，ハーダー腺，精巣，小 腸, 筋肉, 皮覻, 精囊, 精巣上体, 甲状腺, 骨, 眼球, 褐色脂肪および気管中濃度は血漿の $0.8 \sim 0.3$ 倍であ り，血漿とほぼ同程度かそれよりも低い放射能が認めら れた。脳，大腸および脂肪中濃度は低く，血漿の $0.2 〜$

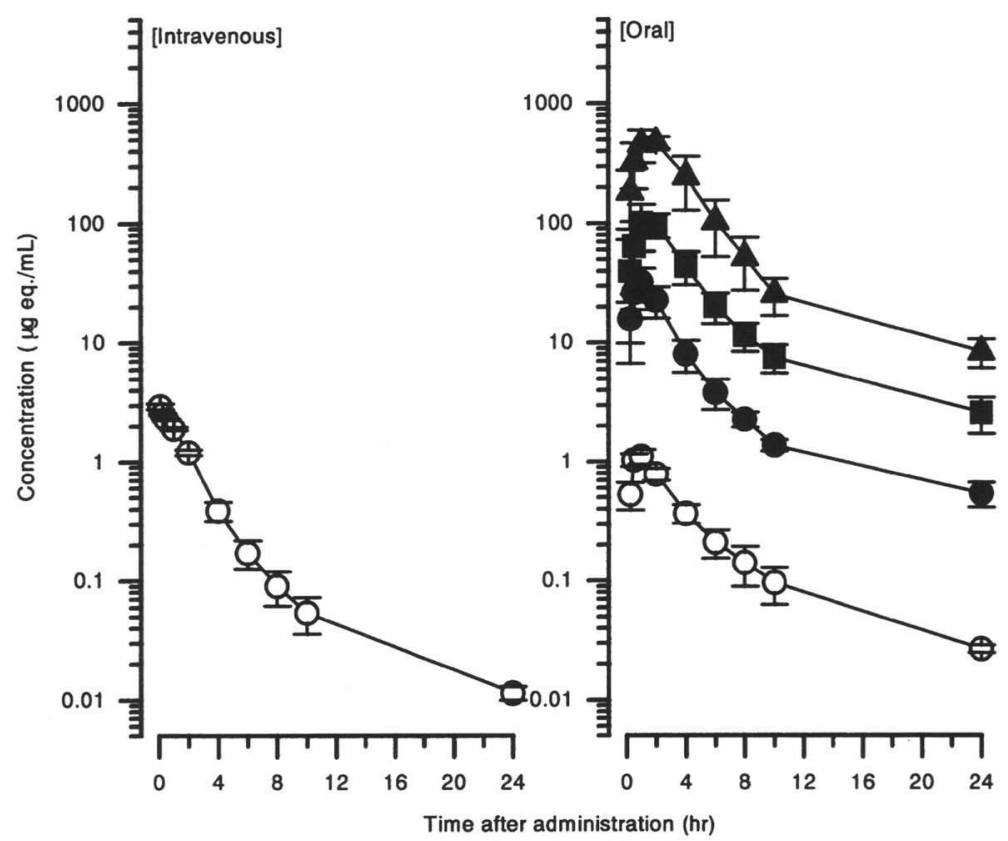

Fig. 1 Plasma radioactivity concentration after intravenous and oral administration of $\left[{ }^{14} \mathrm{C}\right]$ urea in non-fasted rats (Dose: $2-1000 \mathrm{mg} / \mathrm{kg}$ ) Each point represents the mean \pm S.D. of 3 rats. Open circle; $2 \mathrm{mg} / \mathrm{kg}$, Closed circle; $62.5 \mathrm{mg} / \mathrm{kg}$, Square; $250 \mathrm{mg} / \mathrm{kg}$, Triangle; $1000 \mathrm{mg} / \mathrm{kg}$ 
Table I Apparent pharmacokinetic parameters for plasma concentrations of radioactivity after administration of $\left[{ }^{14} \mathrm{C}\right]$ urea in non-fasted rats

\begin{tabular}{|c|c|c|c|c|c|c|}
\hline \multirow{2}{*}{$\underset{\text { Route }}{\text { Administraition }}$} & \multirow{2}{*}{$\begin{array}{c}\text { Dose } \\
(\mathrm{mg} / \mathrm{kg})\end{array}$} & \multirow{2}{*}{$(\mu \mathrm{g}$ eq. $/ \mathrm{mL})$} & \multirow{2}{*}{$\begin{array}{l}\mathrm{T}_{\max } \\
(\mathrm{hr})\end{array}$} & \multicolumn{2}{|c|}{$\mathrm{t}_{1 / 2}$} & \multirow{2}{*}{$\frac{\mathrm{AUC}_{0-\infty}}{(\mu \mathrm{g} \text { eq. } \cdot \mathrm{hr} / \mathrm{mL})}$} \\
\hline & & & & $\alpha(\mathrm{hr})$ & $\beta(\mathrm{hr})$ & \\
\hline Intravenous & 2 & & & $\begin{array}{c}1.7 \\
(5 \mathrm{~min}-10 \mathrm{hr})\end{array}$ & $\begin{array}{c}6.2 \\
(10-24 \mathrm{hr})\end{array}$ & 7.00 \\
\hline \multirow[t]{4}{*}{ Oral } & 2 & $1.10 \pm 0.16$ & 1 & $\begin{array}{c}2.5 \\
(1-10 \mathrm{hr})\end{array}$ & $\begin{array}{c}7.5 \\
(10-24 \mathrm{hr})\end{array}$ & 5.18 \\
\hline & 62.5 & $32.1 \pm 9.7$ & 1 & $\begin{array}{c}2.0 \\
(2-10 \mathrm{hr})\end{array}$ & $\begin{array}{c}10.7 \\
(10-24 \mathrm{hr})\end{array}$ & 123 \\
\hline & 250 & $100 \pm 42$ & 1 & $\begin{array}{c}2.1 \\
(2-10 \mathrm{hr})\end{array}$ & $\begin{array}{c}9.0 \\
(10-24 \mathrm{hr})\end{array}$ & 515 \\
\hline & 1000 & $470 \pm 53$ & 2 & $\begin{array}{c}1.9 \\
(2-10 \mathrm{hr})\end{array}$ & $\begin{array}{c}8.4 \\
(10-24 \mathrm{hr})\end{array}$ & 2374 \\
\hline
\end{tabular}

Values were calculated from the mean plasma concentrations of three animals, except for $\mathrm{C}_{\max }$.

The values of $\mathrm{C}_{\max }$ are expressed as the mean \pm S.D. of 3 rats.

The figures in parentheses show the time periods used for calculation of $t_{1 / 2}$.

0.1 倍であった，投与後 4 時間では，膀脂および腎臓に 血漿中濃度 $286 \mathrm{ng}$ eq. $/ \mathrm{mL}$ のそれぞれ 4.3 倍および 2.5 倍の放射能が認められた。胃は血漿中濃度の 1.5 倍, そ の他の組織中濃度は血漿とほぼ同程度かあるいは低かっ た. 最高濃度に達した後, 各組織中濃度は血漿とほほ平 行に減少したのに対し, 膀腃中濃度は投与後 1 時間以 後 8 時間まで血漿の約 $2 \sim 10$ 倍と高く推移した. 投与 後 24 時間では大腸, ハーダー腺, 胃, 骨䯣, 骨, 肝蔵 等 18 の組織で放射能が認められたが，それらの濃度は 最高濃度の $1 / 10$ 以下に減少した. 投与後 72 時間では 骨, 胃および肝臓に最高濃度の約 1 4\% と低濃度の放 射能が認められたが, その他の組織では測定信頼限界未 満に減少した。なお，松果体および大動脈は測定したい ずれの時点においても測定信頼限界末満であった.

\section{3. 全身オートラジオグラフィー}

非絶食下, ラットに $\left[{ }^{14} \mathrm{C}\right]$ urea $2 \mathrm{mg} / \mathrm{kg}$ の用量で 経口投与後の全身オートラジオグラムを Fig. $2 \mathrm{~A} \sim \mathrm{E}$ に 示す. 投与後 1 時間において腎臓, 膀脂・膀脱尿およ び投与部位である胃および胃内容物中に最も高い放射能 濃度が認められた。 その他の組織は血液と同程度か血液 よりも低加た. 以後, 各組織中放射能濃度は経時的に 減少し, 投与後 4 時間では, 投与後 1 時間と同様に腎 臓, 膀脱・膀脱尿および胃に高い放射能が認められ，大 腸内容物に血液よりもやや高い放射能が認められた。 そ の他の組織中放射能濃度は血液々同程度かそれよりも低 かった. 投与後 8 時間では放射能は腎臓および胃に認 められ, 膀胱および大腸内容物に低濃度認められたが, その他の組織中にはほとんど認められなかった. 投与後 24 時間では放射能は胃に低濃度, 腸管壁および膀脱 . 膀胱尿に極めて低濃度認められたが, 他の組織にはほと
んど認められなかった．投与後 48 時間では胃に極めて 低濃度認められたが，その他の組織からはほぼ完全に消 失した。以上の所見は組織中放射能濃度の所見とほぼ一 致した.

\section{4. 代謝物組成}

1）血墏

非絶食下，ラットに $\left[{ }^{14} \mathrm{C}\right]$ urea を $2 \mathrm{mg} / \mathrm{kg}$ の用量で 経口投与後, 1 時間抢よび 8 時間に打ける血漿のメタ ノール抽出成分のラジオクロマトグラムを Fig. 3 に示 す. 投与後の時間にかかわらず，各血漿のメタノール抽 出成分中にはほぼ未変化体の及が認められた。 なお， 1 時間に抢ける血墏中放射能のメタノール抽出率はほほ 100\%であったが，8 時間では 70\%程度であった(Table III).

2) 尿

非絶食下，ラットに $\left[{ }^{14} \mathrm{C}\right]$ urea を $2 \mathrm{mg} / \mathrm{kg}$ の用量で 静脈内および経口投与後 24 時間をでの尿のラジオクロ マトグラムを Fig. 4 に示す. 尿中には投与経路にかか わらず，ほほ未未変化体のみが認められた。

\section{5. 尿，粪および呼気中放射能排泄}

非絶食下，ラットに $\left[{ }^{14} \mathrm{C}\right]$ urea $2 \mathrm{mg} / \mathrm{kg}$ の用量で 静脈内および経口投与後の呼気, 尿, 糞中放射能排泄率 および屍体中放射能残存率を Table IV に示す．投与後 96 時間までの放射能排泄率は静脈内投与後では尿中に 投与量の $73.1 \%$, 糞中に $1.6 \%$, 呼気中に $20.9 \%$ であ り，経口投与後ではそれぞれ $54.0 \% ， 1.0 \%$ および 42.9 \%であった．呼気中排泄はいずれの投与経路においても 投与後 4 時間より認められた. 投与後 96 時間における 屍体中放射能残存率は静脈内投与で $1.2 \%$ であり, 経口 

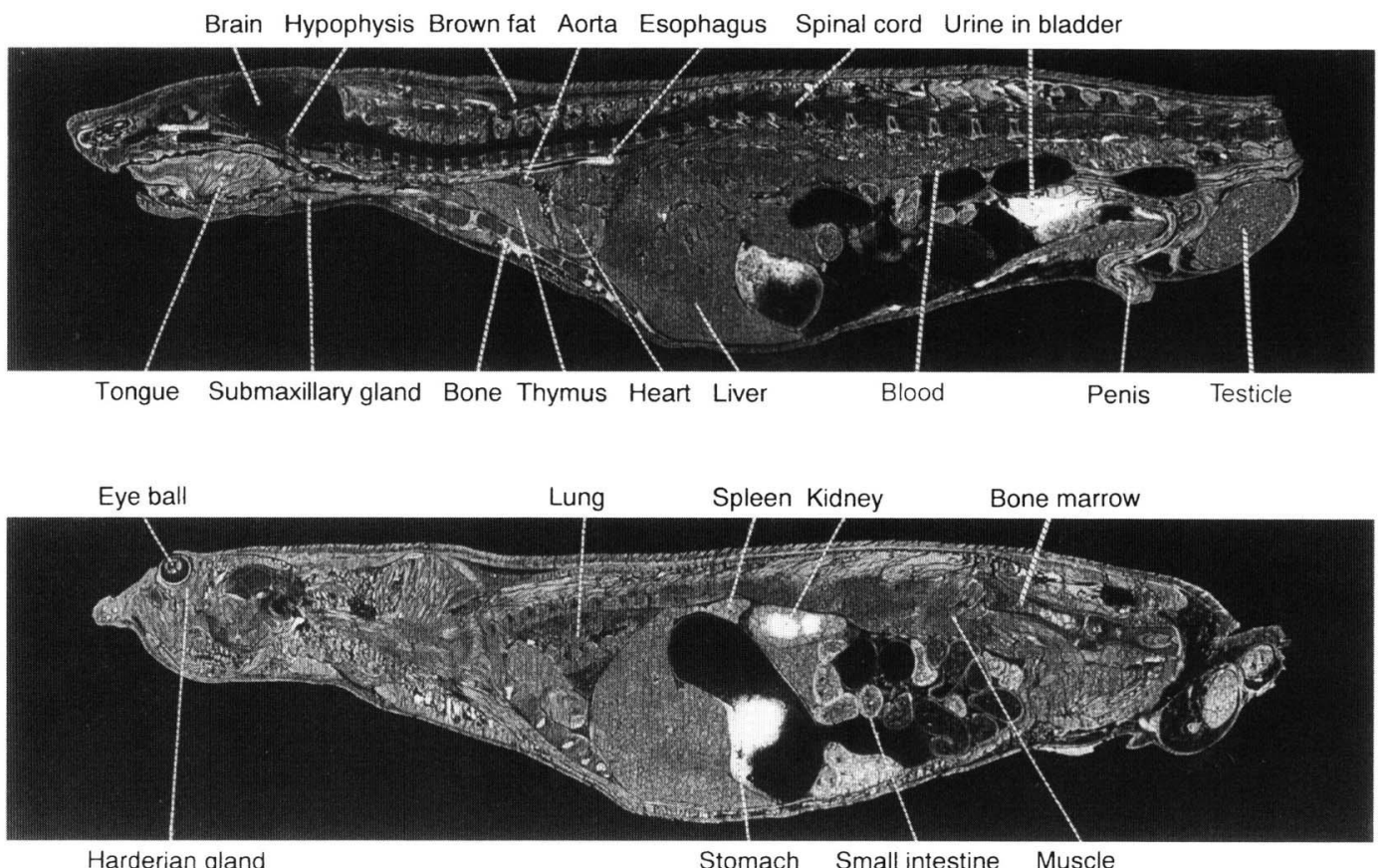

Fig. 2 A : Autoradiograms showing the distribution of radioacrtivity $1 \mathrm{hr}$ after oral administration of $\left[{ }^{14} \mathrm{C}\right]$ urea $(6.99 \mathrm{MBq}$ $(189 \mu \mathrm{Ci}) / 2 \mathrm{mg} / \mathrm{kg})$ in the rat
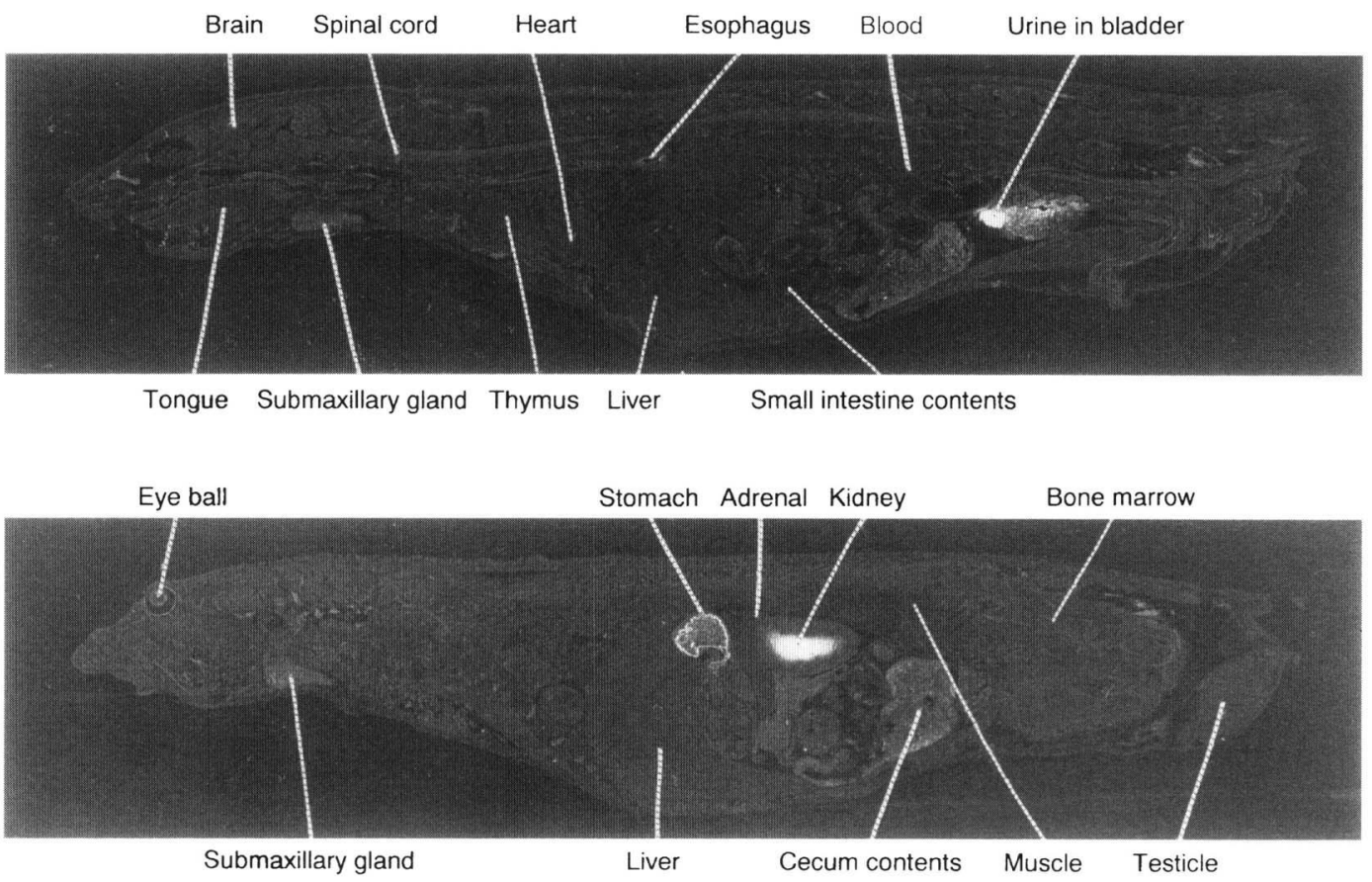

B : Autoradiograms showing the distribution of radioacrtivity $4 \mathrm{hr}$ after oral administration of $\left[{ }^{14} \mathrm{C}\right] \mathrm{urea}(6.99 \mathrm{MBq}(189 \mu \mathrm{Ci})$ $/ 2 \mathrm{mg} / \mathrm{kg}$ ) in the rat 


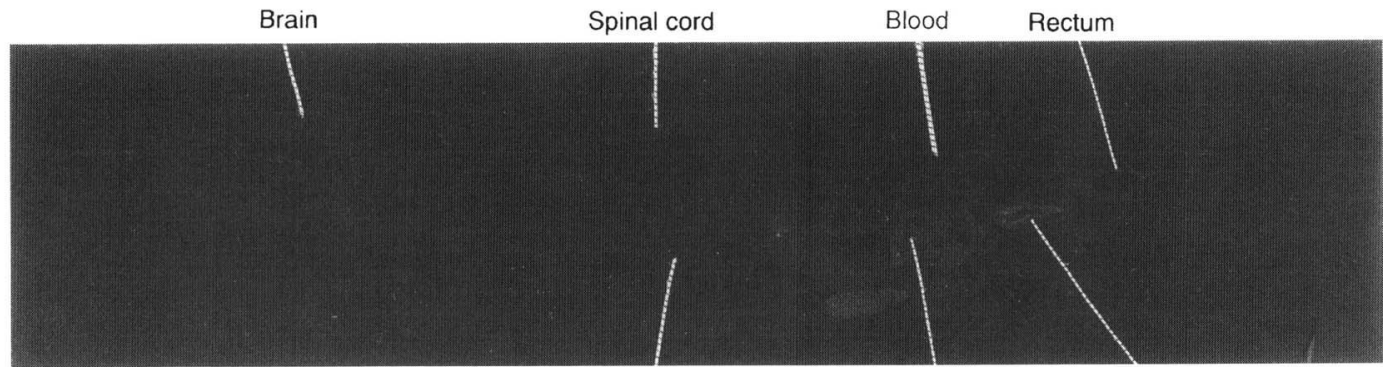

Liver Cecum contents Urinary bladder

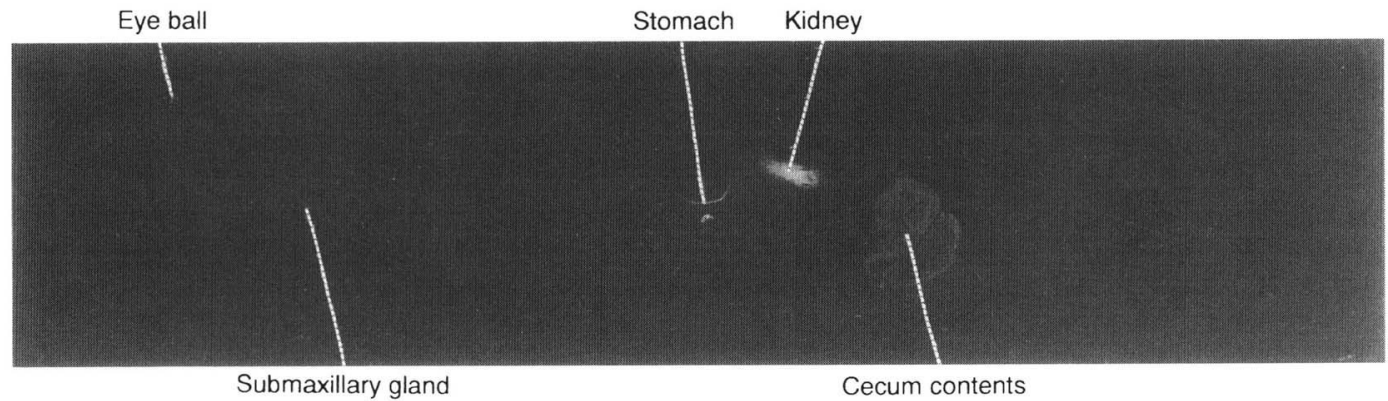

C : Autoradiograms showing the distribution of radioacrtivity $8 \mathrm{hr}$ after oral administration of $\left[{ }^{14} \mathrm{C}\right] \mathrm{urea}(6.99 \mathrm{MBq}(189 \mu \mathrm{Ci})$ $/ 2 \mathrm{mg} / \mathrm{kg}$ ) in the rat

Urine in bladder

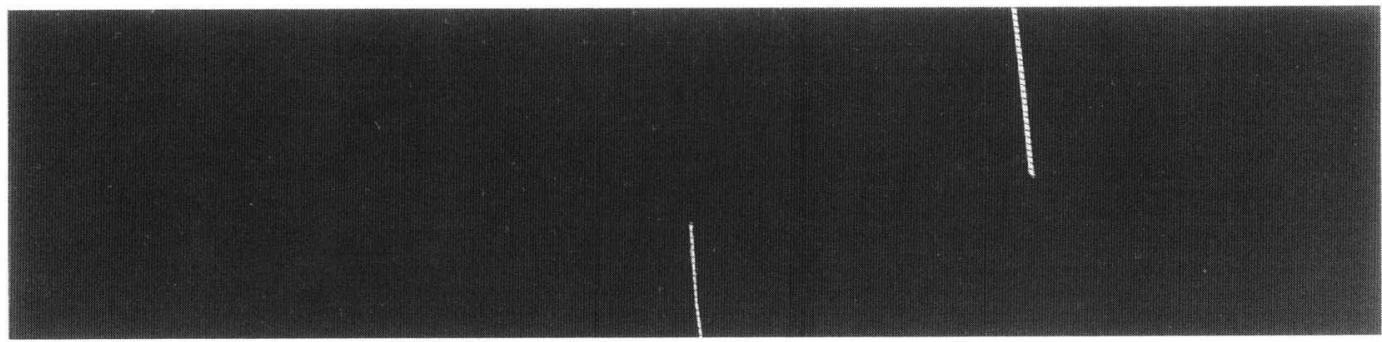

Liver

Stomach Large intestine

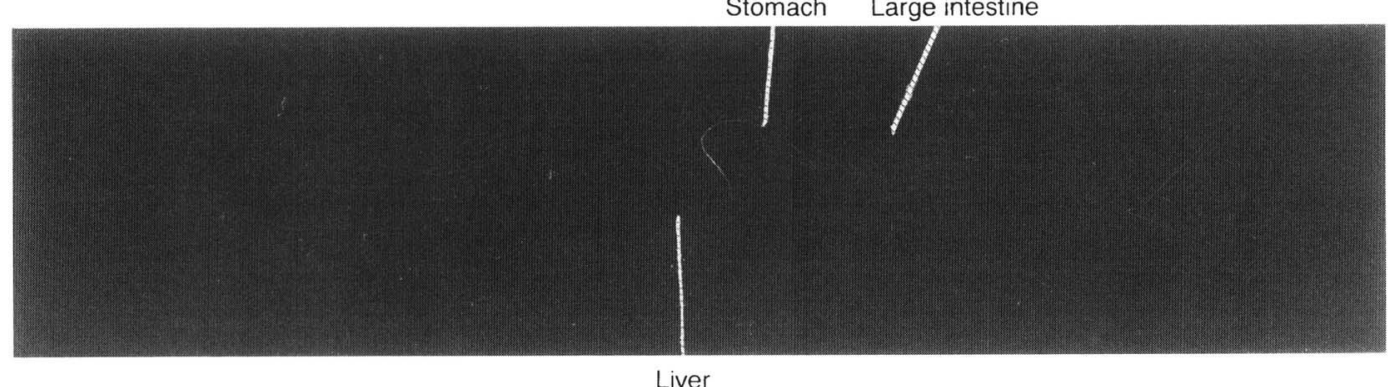

D : Autoradiograms showing the distribution of radioacrtivity $24 \mathrm{hr}$ after oral administration of $\left[{ }^{14} \mathrm{C}\right] \mathrm{urea}(6.99 \mathrm{MBq}(189$ $\mu \mathrm{Ci}) / 2 \mathrm{mg} / \mathrm{kg}$ ) in the rat 


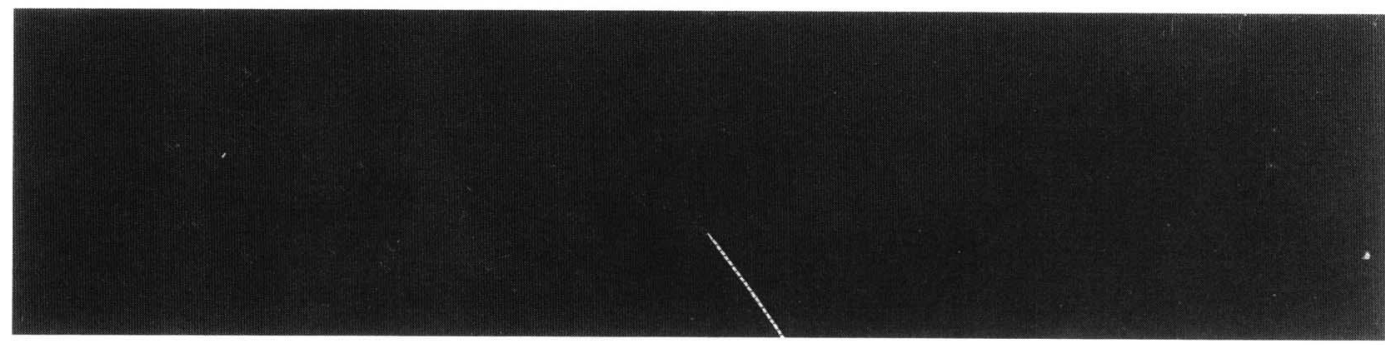

Stomach

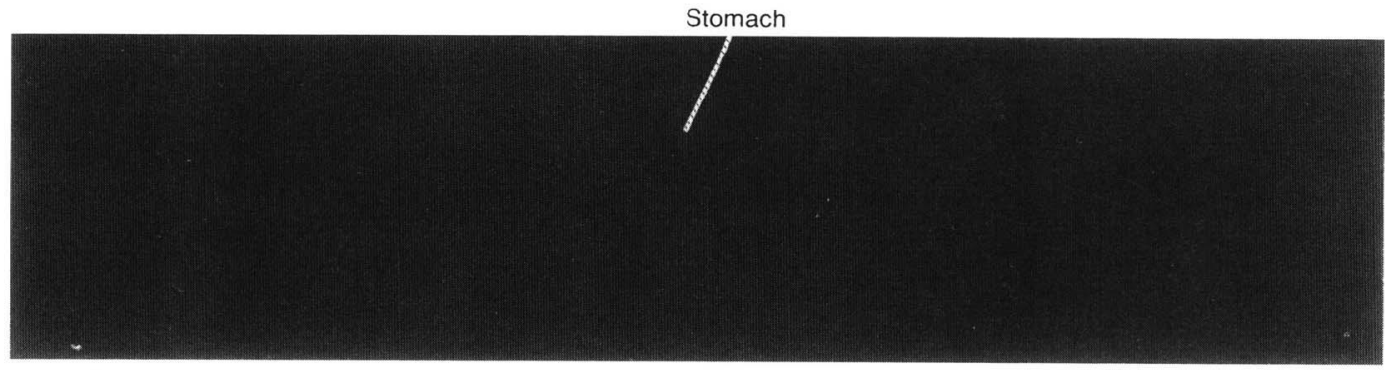

E : Autoradiograms showing the distribution of radioacrtivity $48 \mathrm{hr}$ after oral administration of $\left[{ }^{14} \mathrm{C}\right] \mathrm{urea}(6.99 \mathrm{MBq}(189$ $\mu \mathrm{Ci}) / 2 \mathrm{mg} / \mathrm{kg}$ ) in the rat
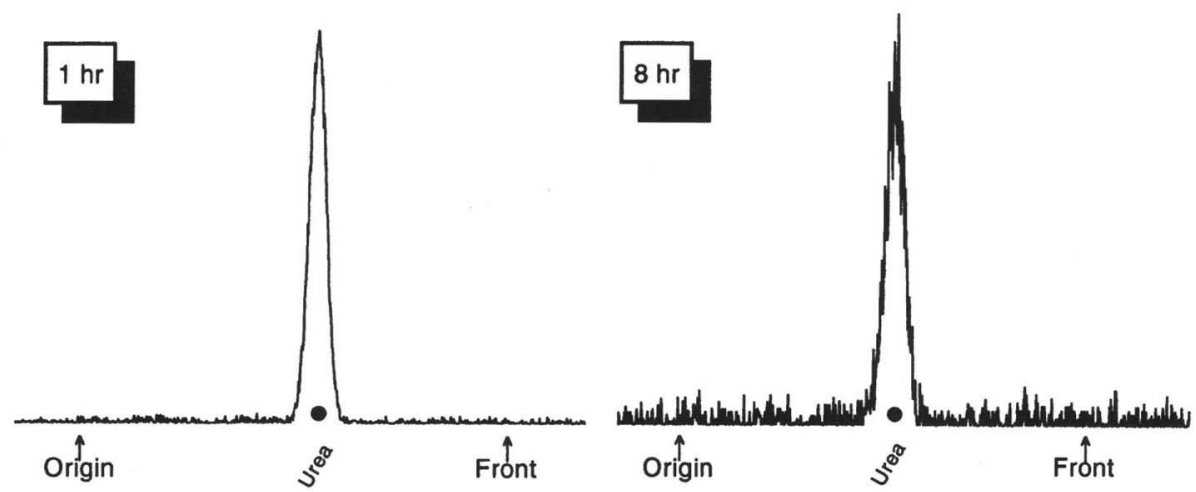

Fig. 3 Thin layer radiochromatograms of plasma at $1 \mathrm{hr}$ and $8 \mathrm{hr}$ after oral administration of $\left[{ }^{14} \mathrm{C}\right] \mathrm{urea}(2 \mathrm{mg} / \mathrm{kg})$ in nonfasted rats

TLC plate, Silica gel $60 \mathrm{~F}_{254}$ (E.Merck)

Solvent system, Ethanol/Distilled water $/ 25 \%$ Ammonia water $=20 / 4 / 1$

投与では放射能は認められなかった。静脈内投与後 96 時間までの尿中放射能排泄率に対する経口投与後のそれ の比より算出した経口吸収率は約 $74 \%$ あったた。

\section{考察}

我々は H. pylori 診断薬としての urea の体内動態を明 らかにすることを目的に， $\left[{ }^{14} \mathrm{C}\right]$ urea を用いて絶食下招 よび非絶食下のラットにおける一連の体内動態試験を実 施した，前報4)では，絶食下に扔ける urea の体内動態 ついて検討した結果, 静脈内および経口投与後いずれも urea はほとんど代謝を受けず，速やかに尿中へ排泄さ れることを明らかにした．本報では非絶食下のラットに $\left[{ }^{14} \mathrm{C}\right]$ urea を投与後の体内動態を明らかにし，絶食下に おける体内動態との比較より，食餌の影響について検討 を加えた。

非絶食下, ラットに $\left[{ }^{14} \mathrm{C}\right]$ urea を $2 \mathrm{mg} / \mathrm{kg}$ の用量で 投与後, 血漿中放射能濃度は静脈内および経口いずれの 投与経路においても， $t_{1 / 2 \alpha}$ 約 2 時間， $t_{1 / 2 \beta}$ 約 7 時間で 二相性に減少した。 また，2 1000 mg $/ \mathrm{kg}$ t経口投与 後の $\mathrm{C}_{\max }$ および $\mathrm{AUC}_{0-\infty}$ は用量にほほ比例して増加 し, 広い用量範囲で線形性が示唆された。絶食下投与 時) における血漿中濃度と比較して(Fig. 5, Table V), 非絶食下投与では経口投与後の $\mathrm{C}_{\max }$ および $\mathrm{AUC}_{0-\infty}$ が それぞれ $44 \%$ 打よび $30 \%$ 低く，静脈内投与後の 
Table II Tissue concentrations of radioactivity after oral administration of $\left[{ }^{14} \mathrm{C}\right] \mathrm{urea}(2 \mathrm{mg} / \mathrm{kg})$ in non-fasted rats

\begin{tabular}{|c|c|c|c|c|c|c|c|c|}
\hline \multirow[b]{3}{*}{ Plasma } & \multicolumn{8}{|c|}{ Concentration (ng eq. $/ \mathrm{mL}$ or $\mathrm{g}$ ) $(\mathrm{T} / \mathrm{P})$} \\
\hline & \multirow{2}{*}{$\frac{30 \mathrm{~min}}{1231 \pm 319(1.0)}$} & \multirow{2}{*}{$\frac{1 \mathrm{hr}}{800 \pm 252(1.0)}$} & \multicolumn{2}{|l|}{$4 \mathrm{hr}$} & \multicolumn{2}{|c|}{$8 \mathrm{hr}$} & $24 \mathrm{hr}$ & $72 \mathrm{hr}$ \\
\hline & & & $286 \pm 30$ & $(1.0)$ & $88 \pm 5$ & $(1.0)$ & $-(-)$ & $(-)$ \\
\hline Blood & $1026 \pm 292(0.8)$ & $677 \pm 220(0.8)$ & $239 \pm 23$ & $(0.8)$ & $72 \pm 8$ & $(0.8)$ & $(-)$ & $(-)$ \\
\hline Red blood cells & $836 \pm 258(0.7)$ & $547 \pm 209(0.7)$ & $167 \pm 14$ & $(0.6)$ & $49 \pm 7$ & $(0.6)$ & $(-)$ & $(-)$ \\
\hline Brain & $210 \pm 44 \quad(0.2)$ & $259 \pm 75 \quad(0.3)$ & $229 \pm 24$ & $(0.8)$ & $110 \pm 19$ & $(1.3)$ & $(-)$ & $(-)$ \\
\hline Pineal body & $-\quad(-)$ & $-\quad(-)$ & - & $(-)$ & - & $(-)$ & $(-)$ & $(-)$ \\
\hline Hypophysis & $925 \pm 204(0.8)$ & $648 \pm 197(0.8)$ & $245 \pm 36$ & $(0.9)$ & - & $(-)$ & $(-)$ & $(-)$ \\
\hline Thyroid & $594 \pm 170(0.5)$ & $465 \pm 211(0.6)$ & $152 \pm 35$ & $(0.8)$ & - & $(-)$ & $(-)$ & $(-)$ \\
\hline Adrenal & $833 \pm 240(0.7)$ & $558 \pm 261(0.7)$ & $217 \pm 22$ & $(0.8)$ & $81 \pm 1$ & $(0.9)$ & $(-)$ & $(-)$ \\
\hline Heat & $826 \pm 202(0.7)$ & $577 \pm 207(0.7)$ & $192 \pm 27$ & $(0.7)$ & $55 \pm 5$ & $(0.6)$ & $(-)$ & $-(-)$ \\
\hline Aorta & $-\quad(-)$ & $-\quad(-)$ & - & $(-)$ & - & $(-)$ & $(-)$ & $-(-)$ \\
\hline Spleen & $970 \pm 265(0.8)$ & $652 \pm 238(0.8)$ & $252 \pm 32$ & $(0.9)$ & $84 \pm 1$ & $(1.0)$ & $-(-)$ & $-(-)$ \\
\hline Thymus & $900 \pm 208(0.7)$ & $661 \pm 252(0.8)$ & $227 \pm 17$ & $(0.8)$ & $73 \pm 1$ & $(0.8)$ & $24 \pm 7(-)$ & $-(-)$ \\
\hline Mesenteric lymph node & $915 \pm 275(0.7)$ & $558 \pm 250(0.7)$ & $220 \pm 25$ & $(0.8)$ & $69 \pm 3$ & $(0.8)$ & $15 \pm 5(-)$ & $-(-)$ \\
\hline Submaxillary lymph node & $876 \pm 235(0.7)$ & $603 \pm 206(0.7)$ & $206 \pm 10$ & $(0.7)$ & $70 \pm 2$ & $(0.8)$ & $19 \pm 6(-)$ & $-(-)$ \\
\hline Submaxillary gland & $969 \pm 234(0.8)$ & $703 \pm 204(0.9)$ & $372 \pm 50$ & (1.3) & $112 \pm 6$ & $(1.3)$ & $17 \pm 5(-)$ & $-(-)$ \\
\hline Tongue & $833 \pm 220(0.7)$ & $626 \pm 227(0.8)$ & $224 \pm 19$ & $(0.8)$ & $70 \pm 3$ & $(0.8)$ & $17 \pm 4(-)$ & $-(-)$ \\
\hline Liver & $1080 \pm 305(0.9)$ & $736 \pm 238(0.9)$ & $291 \pm 42$ & $(1.0)$ & $104 \pm 4$ & $(1.2)$ & $32 \pm 12(-)$ & $15 \pm 4(-)$ \\
\hline Pancreas & $1014 \pm 179(0.8)$ & $768 \pm 188(1.0)$ & $370 \pm 39$ & (1.3) & $83 \pm 8$ & $(0.9)$ & $15 \pm 5(-)$ & $-(-)$ \\
\hline Stomach & $1912 \pm 873(1.5)$ & $1065 \pm 400$ & $416 \pm 31$ & (1.5) & $201 \pm 86$ & $(2.3)$ & $78 \pm 61(-)$ & $43 \pm 32(-)$ \\
\hline Small intestine & $805 \pm 348(0.6)$ & $406 \pm 163(0.5)$ & $194 \pm 25$ & $(0.7)$ & $73 \pm 5$ & $(0.8)$ & $29 \pm 9(-)$ & $-(-)$ \\
\hline Large intestine & $177 \pm 36 \quad(0.2)$ & $277 \pm 106(0.3)$ & $165 \pm 30$ & $(0.6)$ & $68 \pm 8$ & $(0.8)$ & $26 \pm 8(-)$ & $(-)$ \\
\hline Trachea & $330 \pm 47 \quad(0.3)$ & $350 \pm 179(0.4)$ & $128 \pm 24$ & $(0.4)$ & - & $(-)$ & $-(-)$ & $(-)$ \\
\hline Lung & $916 \pm 271(0.7)$ & $622 \pm 219(0.8)$ & $220 \pm 19$ & $(0.8)$ & $72 \pm 4$ & $(0.8)$ & $16 \pm 4(-)$ & $(-)$ \\
\hline Kidney & $2930 \pm 526(2.4)$ & $2154 \pm 635(2.8)$ & $709 \pm 57$ & $(2.5)$ & $295 \pm 42$ & $(3.4)$ & $24 \pm 6(-)$ & $(-)$ \\
\hline Urinary bladder & $1159 \pm 614(0.9)$ & $1369 \pm 324$ & $1286 \pm 1349$ & $(4.3)$ & $934 \pm 732$ & $2(10.4)$ & $-(-)$ & $(-)$ \\
\hline Testicle & $772 \pm 188(0.6)$ & $688 \pm 231(0.9)$ & $245 \pm 29$ & $(0.9)$ & $68 \pm 9$ & $(0.8)$ & $(-)$ & $(-)$ \\
\hline Epididymis & $676 \pm 84 \quad(0.6)$ & $531 \pm 160(0.7)$ & $203 \pm 30$ & $(0.7)$ & $65 \pm 2$ & $(0.7)$ & $-(-)$ & $(-)$ \\
\hline Prostate & $847 \pm 179(0.7)$ & $729 \pm 331(0.9)$ & $262 \pm 38$ & $(0.9)$ & $86 \pm 11$ & $(1.0)$ & $24 \pm 10(-)$ & $(-)$ \\
\hline Seminal vesicle & $703 \pm 136(0.6)$ & $619 \pm 236(0.8)$ & $241 \pm 30$ & $(0.8)$ & $73 \pm 18$ & $(0.8)$ & $19 \pm 6(-)$ & $(-)$ \\
\hline Eye ball & $452 \pm 97 \quad(0.4)$ & $477 \pm 160(0.6)$ & $236 \pm 32$ & $(0.8)$ & $76 \pm 15$ & $(0.9)$ & $-(-)$ & $(-)$ \\
\hline Harderian gland & $783 \pm 208(0.6)$ & $626 \pm 265(0.8)$ & $389 \pm 49$ & (1.4) & $185 \pm 30$ & $(2.1)$ & $96 \pm 32(-)$ & $(-)$ \\
\hline Muscle & $766 \pm 230(0.6)$ & $581 \pm 197(0.7)$ & $183 \pm 20$ & $(0.6)$ & $48 \pm 8$ & $(0.6)$ & $-(-)$ & $(-)$ \\
\hline Fat & $70 \pm 23 \quad(0.1)$ & $58 \pm 31 \quad(0.1)$ & - & $(-)$ & - & $(-)$ & $(-)$ & $(-)$ \\
\hline Brown fat & $421 \pm 45 \quad(0.4)$ & $304 \pm 123(0.4)$ & $119 \pm 25$ & $(0.4)$ & $52 \pm 5$ & $(0.6)$ & $-(-)$ & $(-)$ \\
\hline Skin & $748 \pm 172(0.6)$ & $447 \pm 182(0.5)$ & $168 \pm 24$ & $(0.6)$ & $53 \pm 3$ & $(0.6)$ & $14 \pm 5(-)$ & $-(-)$ \\
\hline Bone & $464 \pm 81 \quad(0.4)$ & $395 \pm 48 \quad(0.5)$ & $203 \pm 7$ & $(0.7)$ & $83 \pm 21$ & $(0.9)$ & $38 \pm 14(-)$ & $20 \pm 4(-)$ \\
\hline Bone marrow & $997 \pm 244(0.8)$ & $679 \pm 206(0.8)$ & $298 \pm 29$ & $(1.0)$ & $117 \pm 11$ & $(1.3)$ & $42 \pm 14(-)$ & $-(-)$ \\
\hline
\end{tabular}

Values are expressed as the mean \pm S.D. of 3 rats.

Dashes show that data were below the reliable limit of measurement.

The values in parentheses show the ratios of radioactivity concentration in tissue relative to that in plasma $(\mathrm{T} / \mathrm{P})$.

Table III Composition ratio of urea in plasma after oral administration of $\left[{ }^{14} \mathrm{C}\right]$ urea $(2 \mathrm{mg} / \mathrm{kg})$ in nonfasted rats

\begin{tabular}{ccc}
\hline Time after dose & $\begin{array}{c}\text { Recovery of } \\
\text { extraction by } \\
\text { methanol } \\
\text { (\% of specimens) }\end{array}$ & $\begin{array}{c}\text { Urea } \\
\text { (\% of total radioac- } \\
\text { tivy in plasma }\end{array}$ \\
\hline $1 \mathrm{hr}$ & $97.1 \pm 5.5$ & $92.8 \pm 6.5$ \\
$8 \mathrm{hr}$ & $70.0 \pm 3.7$ & $68.7 \pm 5.0$ \\
\hline
\end{tabular}

Values are expressed as the mean \pm S.D. of 3 rats.
$\mathrm{AUC}_{0-\infty}$ は $13 \%$ 低く， $\mathrm{t}_{1 / 2 \beta}$ はいずれの投与経路におい ても約 2 倍程度大きかった。 また, 非絶食下における 尿中排泄は経口および静脈内投与後, 絶食下に比べそれ ぞれ投与量の $41 \%$ おび $18 \%$ 低く，それにほぼ対応し て呼気中排泄がそれぞれ $39 \%$ および $16 \%$ 高かった。 Urea は $\mathrm{CO}_{2}$ へ代謝・分解され呼気中へ排泄されること から, 呼気中排泄の増加は urea の代謝・分解が六進し たことを示すものである.このことから, 投与経路にか かわらず urea の代謝・分解は食慨により充進し，その 


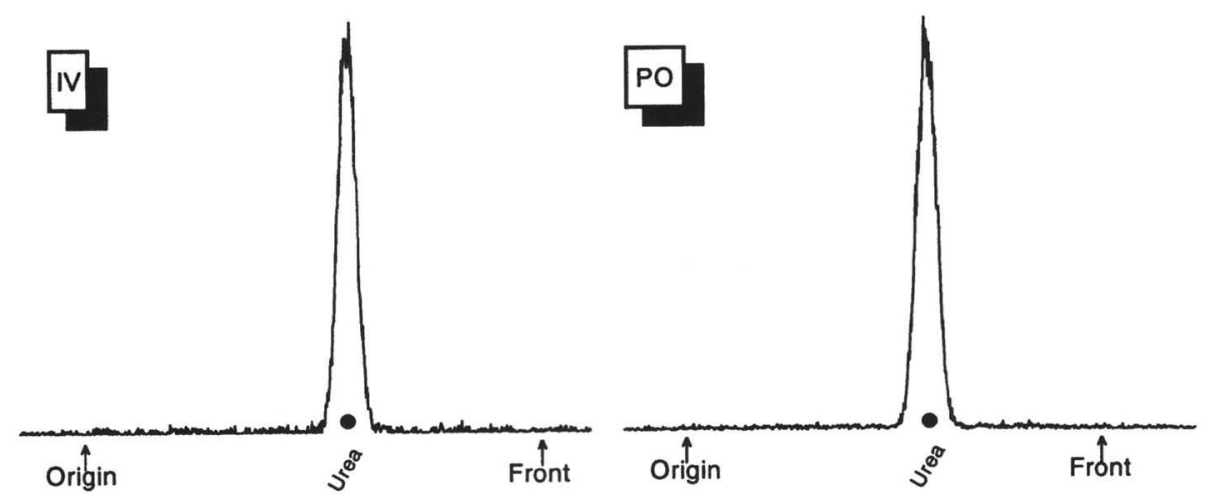

Fig. 4 Thin layer radiochromatograms of $24 \mathrm{hr}$-urine after intravenous and oral administration of $\left[{ }^{14} \mathrm{C}\right] \mathrm{urea}(2 \mathrm{mg} / \mathrm{kg}) \mathrm{in}$ non-fasted rats

TLC plate, Silica gel $60 \mathrm{~F}_{254}$ (E.Merck)

Solvent system, Ethanol/Distilled water $/ 25 \%$ Ammonia water $=20 / 4 / 1$

Table IV Excretion of radioactivity in urine, feces and expired air after administration of $\left[{ }^{14} \mathrm{C}\right]$ urea $(2$ $\mathrm{mg} / \mathrm{kg}$ ) in non-fasted rats

\begin{tabular}{|c|c|c|c|c|c|}
\hline \multirow{2}{*}{$\begin{array}{l}\text { Administra- } \\
\text { tion route }\end{array}$} & \multirow{2}{*}{$\begin{array}{l}\text { Time } \\
\text { period } \\
(\mathrm{hr})\end{array}$} & \multicolumn{4}{|c|}{ Recovery of radioactivity (\% of dose) } \\
\hline & & Urine & Feces & $\underset{\text { air }}{\text { Expired }}$ & Carcass ${ }^{\#}$ \\
\hline \multirow{9}{*}{$\begin{array}{l}\text { Intrave- } \\
\text { nous }\end{array}$} & $0-4$ & & & $10.5 \pm 1.0$ & \\
\hline & $4-8$ & & & $5.4 \pm 1.5$ & \\
\hline & $8-24$ & & & $4.7 \pm 2.6$ & \\
\hline & $0-24$ & $72.6 \pm 5.3$ & $1.6 \pm 0.4$ & $20.5 \pm 2.7$ & \\
\hline & $24-48$ & $0.3 \pm 0.1$ & - & $0.3 \pm 0.2$ & \\
\hline & $48-72$ & $0.2 \pm 0.1$ & - & - & \\
\hline & $72-96$ & $0.1 \pm 0.0$ & - & - & \\
\hline & Washing $2^{2}$ & $0.0 \pm 0.0$ & & & \\
\hline & $0-96$ & $73.1 \pm 5.5$ & $1.6 \pm 0.4$ & $20.9 \pm 2.8$ & $1.2 \pm 0.6$ \\
\hline \multirow[t]{9}{*}{ Oral } & $0-4$ & & & $33.7 \pm 11.2$ & \\
\hline & $4-8$ & & & $5.3 \pm 0.7$ & \\
\hline & $8-24$ & & & $3.8 \pm 4.0$ & \\
\hline & $0-24$ & $53.8 \pm 9.5$ & $1.0 \pm 0.1$ & $42.7 \pm 8.1$ & \\
\hline & $24-48$ & $0.1 \pm 0.0$ & - & $0.2 \pm 0.1$ & \\
\hline & $48-72$ & - & - & - & \\
\hline & $72-96$ & - & - & - & \\
\hline & Washing $2^{2}$ & - & & & \\
\hline & $0-96$ & $54.0 \pm 9.6$ & $1.0 \pm 0.1$ & $42.9 \pm 8.0$ & - \\
\hline
\end{tabular}

Values are expressed as the mean \pm S.D. of 3 rats.

Dashes shown that data were below the reliable limit of measurement. Empty columns show "not examined".

$\# 1$ : Recovery at $96 \mathrm{hr}$ after administration.

$¥ 2$ : Metabolism cage was washed by distilled water at $96 \mathrm{hr}$ after administration.

結果, urea の血漿中動態抢よび排泄動態が变動したも のと推察される. 一方, 各組織/血漿中濃度比は, 絶食 抢よび非絶食下投与間でほぼ等しく, 組織分布挙動自体 に摂䭒状態の影響はないものと考えられる.

以上のように，食餌により urea の体内動態が変動す
ることが明らかとなったが，その影響は経口投与時によ り顕著であった．非絶食下投与時における尿中の放射能 成分は，投与経路によらず未变化体のみであったことか ら, 経口/静脈内投与後の尿中放射能排泄率の比は生物 学的利用率 $(\mathrm{BA})$ に相当すると考えられる.したがって 非絶食下における BA は約 74\% と見積られ，投与量の 約 $26 \%$ が初回通過効果を受けることが示唆された.

Urea の分子量は約 60 と小さく, 小腸からの吸収は $\mathrm{t}_{1 / 2}$ 約 5 分と極めて速やかで良好であり6), 胃からの吸収は 小腸に比べ小さい7)ことが報告されている．このことか ら, 経口投与後 urea は主として小腸より吸収され, 経 口投与された urea が未吸収のまま大腸に至る可能性は 小さいと考えられる. また本検討において, 投与後 4 時間までの呼気中排泄率は静脈内投与では投与量の $10.5 \%$ で呼気中総排泄量の $50 \%$ に達し, 経口投与では $33.7 \%$ で呼気中総排泄量の $79 \%$ に達し，ともに早期よ り呼気中排泄が認められたが, 経口投与後の方がより速 やかであった，以上より，urea は小腸で吸収される前 に初回通過代謝·分解を受けるものと推察される.

食慨により血漿中濃度の $t_{1 / 2 \beta}$ の延長が認められた が, この原因については, 経口投与後 8 時間の血漿中 において絶食下では未変化体以外の代謝物の存在は認め られなかったのに対して, 非絶食下では抽出不可能な放 射能成分 (血墏中放射能の約 30\%) が認められた事実々 の関連より，以下のように推測される。内因性 urea は 消化管において腸内細菌由来の urease により代謝·分 解され, 生成した $\mathrm{NH}_{4}{ }^{+}$は再吸収され, 主として肝臓 で再び urea やアミノ酸あるいはピリミジンの生合成に 利用されることが報告されている8 た $\mathrm{HCO}_{3}-$ も再吸収され, $\mathrm{CO}_{2}$ となって呼気中へ排泄さ れるとともに，一部は生体内で炭酸固定によりオキザロ 酢酸 9 , 脂肪酸 ${ }^{10)}$ あるいはピリミジン11)の生合成に利用 


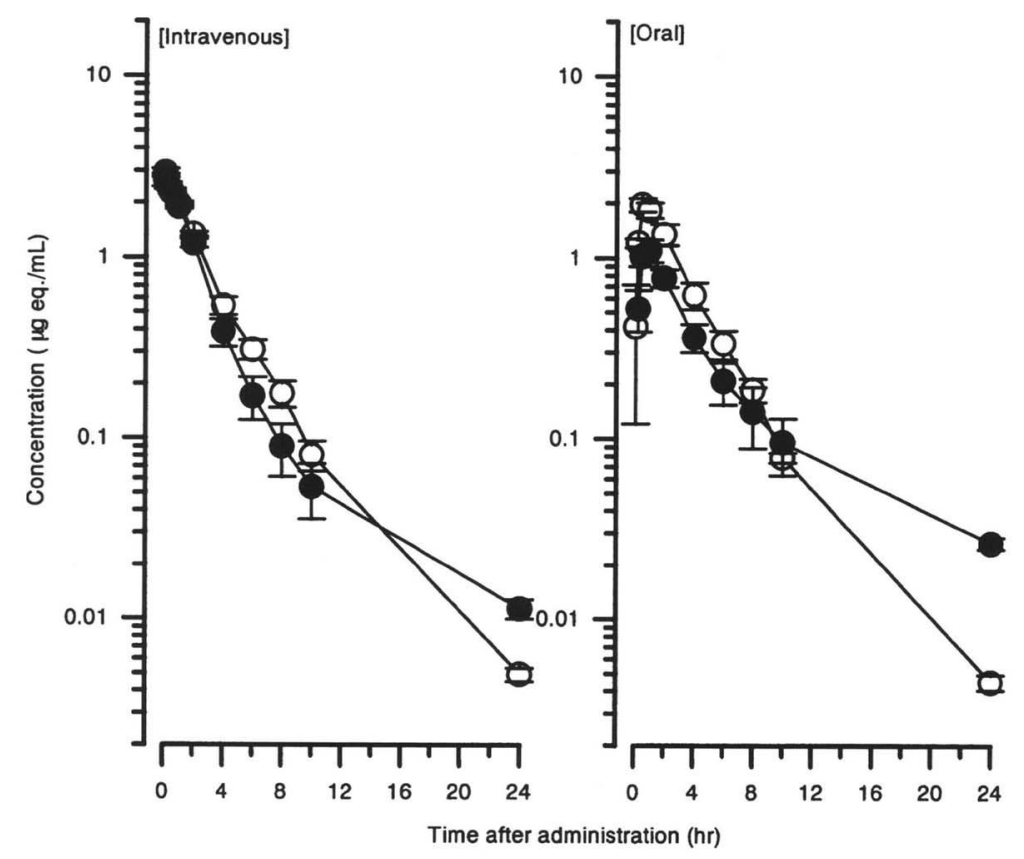

Fig. 5 Plasma radioactivity concentration after intravenous and oral administration of $\left[{ }^{14} \mathrm{C}\right]$ urea in non-fasted and fasted rats (Dose: $2 \mathrm{mg} / \mathrm{kg}$ )

Each point represents the mean \pm S.D. of 3 rats.

Closed circle; Non-fasted rats, Open circle; Fasted rats ${ }^{4)}$

Table V Comparison between fasted ${ }^{4)}$ and non-fasted rats for pharmacokinetic parameters of plasma radioactivity concentration and expiratory and urinary excretion of radioactivity after intravenous and oral administration of $\left[{ }^{14} \mathrm{C}\right] \mathrm{urea}(2 \mathrm{mg} / \mathrm{kg})$

\begin{tabular}{|c|c|c|c|c|c|c|}
\hline \multirow{2}{*}{ Parameters } & \multicolumn{3}{|c|}{ Intravenous administration } & \multicolumn{3}{|c|}{ Oral administration } \\
\hline & Fasted & Non-fasted & $\Delta(\%) \# 3$ & Fasted & Non-fasted & $\Delta(\%) \# 3$ \\
\hline $\mathrm{C}_{\max }(\mu \mathrm{g}$ eq. $/ \mathrm{mL})$ & & & & 1.96 & 1.10 & $-44 \downarrow$ \\
\hline $\operatorname{AUC}_{0-\infty}(\mu \mathrm{g}$ eq. $\cdot \mathrm{hr} / \mathrm{mL})$ & 8.06 & 7.00 & $-13 \downarrow$ & 7.43 & 5.18 & $-30 \downarrow$ \\
\hline $\mathrm{t}_{1 / 2 \beta}(\mathrm{hr})$ & 3.5 & 6.2 & $77 \uparrow$ & 3.4 & 7.5 & $121 \uparrow$ \\
\hline Expiratory excretion ${ }^{\# 1}$ ( $\%$ of dose) & 4.7 & 20.9 & $16 \uparrow$ & 3.5 & 42.9 & $39 \uparrow$ \\
\hline Urinary excretion ${ }^{\# 1}$ (\% of dose) & 91.1 & 73.1 & $-18 \downarrow$ & 95.1 & 54.0 & $-41 \downarrow$ \\
\hline 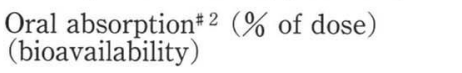 & & & & 104 & 74.0 & $-30 \downarrow$ \\
\hline
\end{tabular}

\#1: Excretion rate for $96 \mathrm{hr}$ after administration of $\left[{ }^{14} \mathrm{C}\right]$ urea.

\#2: Caculated from ratio of urinary excretion rate after oral administration to intravenous administration.

\#3 : Calculated from “(Non-fasted - Fasted) /Fasted $\times 100(\%)$ " for $\mathrm{C}_{\max } \mathrm{AUC}_{0-\infty}$ and $\mathrm{t}_{1 / 2}$ and "Non-fasted (\%) - Fasted (\%)" for expiratory and urinary excretion and oral absorption (bioavability).

され，さらに生体高分子に組み込まれることが知られて いる. 非絶食下のラット血漿中に抽出不可能な放射能成 分が認められたのは， $\left[{ }^{14} \mathrm{C}\right]$ urea の分解により生じた $\mathrm{H}^{14} \mathrm{CO}_{3}$ - が上記の生体成分の生合成に再利用され生体 高分子に組み込をれたことを示唆している．このように， urea の代謝・分解が六進している非絶食下のラットに 打いては， $\mathrm{H}^{14} \mathrm{CO}_{3}$ - の再利用による放射性代謝物が, ある程度の時間経過後より出現するために, 絶食下より も血漿中放射能濃度の $\mathrm{t}_{1 / 2 \beta}$ が長くなったものと推察さ れる.
以上のように, 前報)での urea の絶食下ラットにお ける体内動態の結果と本報での非絶食下ラットにおける 結果の比較より, 投与経路にかかわらず食餌により urea の血墏中動態㧍よび排泄動態が変動することが明 らかとなった．この変動は食䬣による urea の代謝・分 解活性の克進に起因するものと推察され, その影響は経 口投与時により顕著に現れた. 前述のように, 内因性 urea は消化管において代謝・分解を受けることが報告 されているが8)，urea を経口投与後の初回通過代謝·分 解部位および静脈内投与後または吸収後全身循環血中に 
入った urea の代謝・分解部位についてはいずれも未確 認である. $\left[{ }^{13} \mathrm{C}\right]$ Urea を用いる H. pylori 診断に抢い て，食䬣の影響を考慮することの重要性から，今後， urea の代謝·分解機構についてさらに詳細に検討する 必要があるものと考えられる。

\section{要約}

非絶食下， $\left[{ }^{14} \mathrm{C}\right]$ urea を主として $2 \mathrm{mg} / \mathrm{kg}$ の用量でラ ットに単回静脈内および経口投与後の吸収, 分布, 代 謝, 排泄について検討した。 また，本体内動態を絶食下 における体内動態と比較検討した.

1. 血漿中放射能濃度は, 投与経路および用量にかか わらず $\mathrm{t}_{1 / 2 \alpha} 2 \sim 3$ 時間, $\mathrm{t}_{1 / 2 \beta} 6 \sim 11$ 時間で二相性に減少し た. $2 \sim 1000 \mathrm{mg} / \mathrm{kg}$ 経口投与後の $\mathrm{C}_{\max }$ および $\mathrm{AUC}_{0-\infty}$ は用量にほぼ比例しており, 本用量範囲で線形性が示唆 された。

2. 血漿および各組織中放射能濃度は経口投与後 30 分ないし 1 時間で最高濃度に達し, 腎臓中濃度が最も 高く血墏中濃度の 2.4 倍であり, その他の組織中濃度は 血漿とほぼ同程度かそれよりも低かった，以後，大部分 の組織中濃度は血漿中濃度とほほ平行して減少した。

3. 経口投与後 1 時間における血漿中には未变化体の

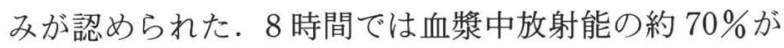
未変化体であったが，それ以外に抽出不可能な未知代謝 物の存在が認められた．また，尿中には投与経路にかか わらず未変化体の及が認められた。

4. 投与後 96 時間までの放射能排泄率は静脈内投与 後では尿中に投与量の $73.1 \%$, 糞中に $1.6 \%$, 呼気中に $20.9 \%$ であり，経口投与後ではそれぞれ $54.0 \% ， 1.0 \%$ および $42.9 \%$ であった. 経口/静脈内投与後の尿中未変 化体排泄率の比より BA は約 $74 \%$ と推定された。

5. 絶食下と非絶食下で比較した結果, 食餌により urea の代謝・分解が元進し, 血墏中動態および排泄動 態が変動することが示唆された。

\section{文献}

1) Pathak, C. M., Bhasin, D. K., Panigrahi, D. and Goel, R. C.: Evaluation of ${ }^{14} \mathrm{C}$-urinary excretion and its comparison with ${ }^{14} \mathrm{CO}_{2}$ in breath after ${ }^{14} \mathrm{C}$-urea administration in Helicobacter pyroli infection. Am. J. Gastroenterology., 89 (5): 734-738 (1994).

2) Thijs, W. J., Thijs, J. C., Kleibeuker, J. H., Elzinga, H. and Stelaard, F.: Evaluation of clinical and home performance of the ${ }^{13} \mathrm{C}$-urea breath test for the detection of Helicobacter pylori. European Journal of Gastroenterology and Hepatology., 7(7): 603-607 (1995).

3) Munster, D. J., Chapman, B. A., Burt, M. J., Dobbs, B. R., Allardyce, R. A., Bagshaw, P. F., Troughton, W. D. and Cook, H. B.: The fate of ingested ${ }^{14} \mathrm{C}$-urea in the urea breath test for Helicobacter pylori infection. Scand. J. Gastroenterol., 28: 661-666 (1993).

4) 野村成章, 松本 聡, 西村由香, 寺内嘉章, 藤井敏彦, 関 英昌, 市毛一美, 佐久間智子 : $\left[{ }^{14} \mathrm{C}\right]$ Urea の体内動態 (第 1 報）; 絶食ラットにおける吸収, 分布, 代謝, 排泄. 薬 物動態, 16(6): 000-000 (2001).

5) Miyazaki, H., Matsunaga, Y., Nambu, K., Oh-e, Y., Yoshida, K. and Hashimoto, M.: Disposition and metabolism of $\left[{ }^{14} \mathrm{C}\right]$ haloperidol in rats. Arzneim.-Forsch./Drug Res., 36 (1), 3: 443-452 (1986).

6) Yuasa, H, Iga, T, Hanano, M. and Watanabe, J.: Relationship between in vivo first-order intestinal absorption rate constant and the membrane permeability clearance. Journal of Pharmaceutical Science, 78(11): 922-924 (1989).

7) Brandell, R. A., Scaletscky, R. and Koch, M. O.: Urinary solute transport by gastric mucosa: A comparison with ileum using a rat model. Urology, 44(3): 343-347 (1994).

8) Ejiri, K.: Studies on entero hepatic circulation of urea nitrogen in pregnant rat. Acta. Obst. Gynaec. Jpn., 32(5): 601610 (1980).

9）千葉英雄, 佐々木隆造 : 糖代謝とその制御, 蛋白質核酸酵 素(臨時増刊), 22(14): 1699-1711 (1977).

10) Wakil, S. J.: A malonic acid derivative as an intermediate in fatty acid synthesis. J. Am. Chem. Soc., 80: 6465 (1958).

11）日本生化学会 (編)：細胞機能と代謝マップI . 細胞の代 謝·物質の動態. 東京化学同人：188-191 (1997). 